\title{
WINTER GRAZING VERSUS SUPPLEMENTS - CHEAPER DAIRYING SYSTEMS
}

Abstract

Present economics dictate New Zealand dairy farmers either increase production or reduce expenditure to maintain net farm income. Costs associated with present feed conservation practices are high and so cheaper alternatives for bridging a winter feed deficit are considered.

Making no conservation would mean generating additional feed energy by foregoing some milkfat production. Lower cow conversion ratios of milkfat from pasture in late lactation means it is more economic to create additional feed at the end of the season by drying-off earlier rather than calving later. Utilising additional cow liveweight as a store of energy has high metabolic inefficiencies.

At today's prices, grazing cows off to overcome the deficit is the most economic and practical solution.

Economically, alternatives to traditional supplement systems require a massive reduction of capital farm machinery to be viable.

Management strategies, both to control the spring feed surplus and to increase average farm herbage masses in early winter without loss of growth or quality, need to be developed.

\section{INTRODUCTION}

The present economic downturn in the dairy industry has left farmers questioning all areas of expenditure. The cost of conserving supplements including vehicle costs is the largest variable cost faced by New Zealand factory-supply dairy farmers (NZDB Economic Survey 1984-85). However, a no-conservation system, while saving expenses, may result in reduced production.

The Stratford Demonstration Farm is used as an example to compare the present supplement policy with all grass/no-conservation options available.

\section{THE PRESENT SITUATION}

The Stratford Demonstration Farm comprises 44 ha (42 eff. ha) at $305 \mathrm{~m}$ a.s.I. It is presently wintering 140 Jersey cows and 32 yearling replacements. Mean calving date is 25 August and drying-off is in early May. Production has averaged $19700 \mathrm{~kg} \mathrm{MF}$ or $470 \mathrm{~kg}$ MF/ha over the last three seasons. Both stocking rate (3.7 cow eq. per eff. ha) and milkfat production are about $30 \%$ above district average. The farm annually grows about 12.0 tonnes of dry matter (Roberts \& Thomson 1984).

Normal district conservation policies are used. Approximately $35,000 \mathrm{~kg}$ DM (15 bale eq per cow eq.) is conserved in the ratio of 2 silage : 1 hay.

A summary of average expenditure costs associated with supplements over the last three seasons is detailed in Table 1.

Direct and indirect costs of $\$ 8880$ are associated with the growing, collection, storage and reallocation of conserved feed at the Demonstration Farm. This figure is typical of the district and represents $\$ 21 \mathrm{O} / \mathrm{ha}, \$ 56 / \mathrm{cow}$ eq. or $25 \mathrm{c} / \mathrm{kg} \mathrm{DM}$ conserved. In other terms $\$ 56$ per cow at $\$ 3.10 / \mathrm{kg} \mathrm{MF}$ represents $18 \mathrm{~kg}$ MF or the production for the last $4-5$ weeks of lactation.

While $35,000 \mathrm{~kg}$ DM is conserved, feed budgets and practical experience suggests $700 \mathrm{~kg} \mathrm{DM} / \mathrm{ha}$ or $190 \mathrm{~kg} \mathrm{DM} / \mathrm{cow}$ is required to correct the winter feed deficit under current management.

Supplements provide for this deficit, as well as improving herbage quality post harvest (Sheath et a/. 1987) and animal production. 
Table 1: Associated costs of making supplements for the Stratford Demonstration Farm. Average of $84 / 85,85 / 86$ and $86 / 87$ seasons.

\begin{tabular}{|c|c|c|c|}
\hline & & Total & ha \\
\hline Silage making & & $\$ 1974$ & $\$ 47$ \\
\hline Hay making & & $\$ 765$ & $\$ 18$ \\
\hline Tractor expenses' & & 52329 & $\$ 55$ \\
\hline Tractor/machinery depreciation2 & & 51784 & $\$ 43$ \\
\hline Barn/silage pitraces ${ }^{3}$ & & 51000 & $\$ 24$ \\
\hline Additional fertiliser ${ }^{4}$ & & 5940 & $\$ 22$ \\
\hline & TOTAL & 56792 & 5209 \\
\hline
\end{tabular}

1 Assumed $80 \%$ of tractor costs are associated with supplements

2 Assumed $80 \%$ of tractor and machinery depreciation is related to supplements

3 Estimated figure for the maintenance of supplement storage facilities

${ }_{4}^{4}$ All supplement paddocks receive an additional $125 \mathrm{~kg} / \mathrm{ha}$ of muriate of potash

Averages have been calculated at 86187 dollar values.

\section{OTHER WINTERING SYSTEMS}

1. Carry supplements into winter in the form of standing hay. Little data is available on the effect of quality and quantity of this type of stored pasture, or resultant changes in composition and persistence.

Work with beef animals suggests the quality will be less than poor hay (G. W. Sheath pers comm.). L'Hullier and Aislabie (this volume) suggest standing hay will enhance autumn and winter growth rates through natural reseeding,

While the economics of such a system are difficult to determine there would be a saving in harvesting costs, while providing a bank of feed - even if of dubious quality - going into winter.

2. Destock the farm during winter to reduce animal demand by $700 \mathrm{~kg} \mathrm{DM} / \mathrm{ha}$. Thirty-eight days of grazing off the whole herd would achieve this $(700 \mathrm{~kg} \mathrm{DM} / \mathrm{ha}) /(3.7$ cows/ha $x 5 \mathrm{~kg} \mathrm{DM} / \mathrm{cow} /$ day).

This assumes the maintenance requirement is $5.0 \mathrm{~kg}$ DM per day and this is saved via grazing out.

Grazing out at $\$ 6.00 /$ cow $/$ week sums to a total cost of $\$ 120 / \mathrm{ha}$.

3. Dry-off early and use the grass that would have gone into milk production to lift cow condition. Cows are then fed sub-maintenance throughout the remainder of the winter utilising this additional cow weight.

Using 0.37 as the efficiency of utilisation of metabolisable energy for liveweight gain of a non-lactating cow feed autumn pastures of $10 \mathrm{MJME} / \mathrm{kgDM}$ (Holmes and Wilson 1984), a cow will need to consume an additional $514 \mathrm{~kg}$ DM to have a pasture sparing effect in winter of $190 \mathrm{~kg}$ DM. This would involve putting on nearly two condition scores above normal.

Holmes \& McMillan (1982) show late lactation efficiency of conversion of pasture dry matter to milkfal to be 15-24:1. Assuming an average of 20:1, $514 \mathrm{~kg}$ DM represents $26 \mathrm{~kg}$ MF and at $\$ 3.10 / \mathrm{kg} \mathrm{MF}$ payout, this is equivalent to $\$ 298 / \mathrm{ha}$.

4. Increase winter feed supply by drying-off early and carrying $190 \mathrm{~kg} \mathrm{DM} / \mathrm{cow}$ of autumn feed into winter. At a conversion of $20 \mathrm{~kg}$ DM/ $\mathrm{kg} \mathrm{MF,} 190 \mathrm{~kg}$ DM will mean a decrease in production of $10 \mathrm{~kg} \mathrm{MF} /$ cow. At 3.7 cows $/$ ha and $\$ 3.1 \mathrm{O} / \mathrm{kg} \mathrm{MF}$ this is a cost of $\$ 115 / \mathrm{ha}$.

5. Use present autumn/winter management, but without supplements and calve later with less average farm herbage mass. Again $190 \mathrm{~kg} \mathrm{DM} / \mathrm{cow}$ will be the pasture deficit. Efficiency of conversion of pasture to milkfat in early lactation is 13:1 (Holmes and McMillan 1982 ). Therefore, there will be a loss of $15 \mathrm{~kg} \mathrm{MF} /$ cow which represents a cost of $\$ 172 / \mathrm{ha}$.

\section{CONTROLLING SPRING SURPLUSES}

If a complete management system is to be developed around an all grass wintering there must be some changes in spring management to control surplus feed. 
The use of set-stocking or very fast rotations at the time of surplus feed will reduce herbage accumulation rates (Bryant \& L'Hullier 1986) and increase intake and production of the grazing cow (N. A. Thomson, unpublished data).

Somatotropin injections have been shown to increase animal intakes (Peel et al. 1985) and if administered at the onset of spring herbage surpluses, could assist in controlling these.

A reduction in the amount of spring fertiliser applied may reduce peak spring growth rates.

\section{DISCUSSION}

Table 2 shows the cost comparisons associated with the various wintering systems described above. Conventional conservation systems not only suffer from high costs, but also high dry matter losses. Losses from harvest to feeding out have been measured at $24 \%$ and $42 \%$ for hay and silage respectively (Thomson 1986).

Economically the 'dry-off early/carry autumn grass forward' option is good. Although there are problems in achieving this while retaining pasture quality and production. The Stratford Demonstration Farm needs an average herbage mass of $2350 \mathrm{~kg} \mathrm{DM} /$ ha at the start of June. This enables a target herbage mass of $2050 \mathrm{~kg} \mathrm{DM} / \mathrm{ha}$ at mean calving date to be achieved, given that $700 \mathrm{~kg} \mathrm{DM} / \mathrm{ha}$ is available as supplements. This represents a feed wedge from 1200 to $3500 \mathrm{~kg}$ DM/ha (see figure 1a). The feed wedge would need to be from 1200 to $4800 \mathrm{~kg}$ DM/ha with an average of $3050 \mathrm{~kg} \mathrm{DM} / \mathrm{ha}$, to carry an additional $700 \mathrm{~kg}$ DM/ha of pasture.

Table 2: The costs associated with different wintering systems

\begin{tabular}{lc}
\hline System & \$ per ha \\
\hline Standing hay system & 7 \\
Dry-off early. Carry autumn grass forward & $\$ 115$ \\
Graze cows out during winter & $\$ 120$ \\
Calve later with less feed & $\$ 172$ \\
Present supplement policy & $\$ 210$ \\
Dry off early. Increase cow condition & $\$ 298$ \\
\hline
\end{tabular}

Brougham (1960) and Piggot et al. (1987) have shown pastures reach a ceiling yield where net herbage accumulation is zero. These ceiling yields vary with season. Taranaki ryegrass/clover pastures reach ceiling yields at $4000 \mathrm{~kg}$ DM/ha in late autumn (N. A. Thomson pers comm). Obviously it would be impossible to achieve a feed wedge of average herbage mass of $3050 \mathrm{~kg} \mathrm{DM} / \mathrm{ha}$ as a high proportion of the farm would be at ceiling yield, This would reduce the overall farm'net herbage accumulation rate (see figure lb). There would also be a decline of pasture quality and subsequent animal production (Hoogendoorn et $a /$. 1987).

In late autumn the use of on-off grazing at a trigger herbage mass (say $3200 \mathrm{~kg} \mathrm{DM} / \mathrm{ha}$ ), to control animal intake at maintenance, may improve net accumulation rates. No paddocks would be at ceiling yield and the bottom end of the feed wedge would be lifted with the resultant feed profile being more of a rectangle (see figure Ic).

Cutting trials have shown higher herbage masses do not enhance winter herbage accumulation rates (N.A. Thomson, unpublished data). The opposite has been shown under grazing dry cows (Santamaria \& McGowan 1982). This would support the need for a feed profile approaching a feed rectangle.

The cost of grazing off will depend on supply/demand. If this practice was adopted district-wide the demand for grazing will increase the price, and reduce the profitability.

There is higher efficiency of conversion of pasture dry matter to milk production in early lactation over late lactation. This results in a greater reduction in milkfat in spring compared with autumn, given the same amount of feed being diverted from milkfat production to cover 
the deficit. Therefore it is more important to investigate management systems to correct winter feed deficits by shortening the lactation at the point where feed conversion efficiencies are lowest.

The metabolic losses of energy in the use of pasture for liveweight gain are high, particularly in the non-lactating cow fed on autumn quality pasture (Holmes \& Wilson 1984) The use of the cow to carry a store of energy, in the form of extra condition, to make up a deficit results in poor economics due to these high metabolic inefficiencies.

Nitrogen was not considered as an option to correct the deficit. It is impractical to use nitrogen, at response rates of $7 \mathrm{~kg} \mathrm{DM} / \mathrm{kg} \mathrm{N}$ to correct a deficit of $700 \mathrm{~kg} \mathrm{DM} / \mathrm{ha}$. There would be insufficient area to spread nitrogen at optimal rates given the amount required.
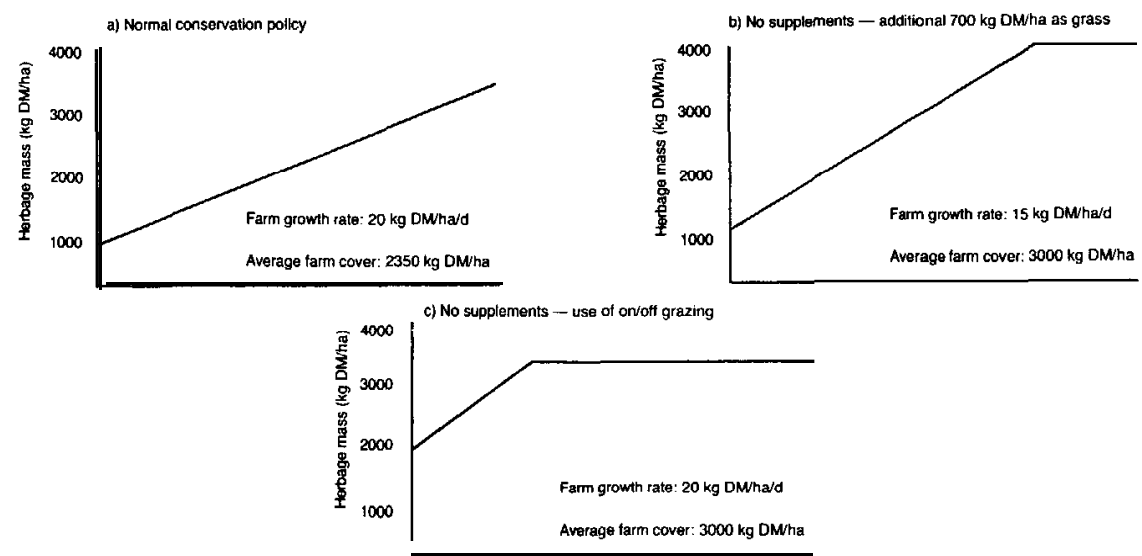
rigure 1: Ristrihution of feed across farm, average growth rates and average farm pasture covers at the 1 st June under
different grazing management systems. (a) normal conservation policy; (b) no supplements carrying additional $700 \mathrm{~kg}$ DM/ha as grass; (c) no supplements use of on/off grazing.

\section{CONCLUSIONS}

More investigation needs to be conducted on alternatives to present conservation systems and the associated pasture and grazing management required. This will ensure New Zealand farmers have systems available to maximise net dollar return.

\section{References}

Brougham R.W. 1960. Pasture growth and grazing management. Dairytarmers Annual 9: 51-62

Bryant A.M., L'Huillier P.J. 1986. Better use of pastures. Proceedings 1986 Ruakura Farmers Conference. pp. 43-53

Holmes C.W., McMillan K.L. 1982. Nutritional management of the dairy herd grazing on pasture. In: McMillan K.L., Taufa V.K. (Eds). Proceedings of the Conference on Dairy Production from Pasture. pp. 244-274

Holmes C.W.. Wilson G.F. 1964. Principles of Nutrition, In: Holmes C.W., Wilson G.F. (Eds) Milk Production from Pastures. pp. 107-112

Hoogendoorn C.J.. Holmes C.W., Ryan M.P. 1987. The influence of pasture regrowth interval in winter on sward characteristics and dairy cow performance in early spring. In: Proceedings 4th AAAP Science Congress, p. 143

Peel C.J., Sandles L.D.. Quelch K.J., Herington A.C. 1965. The effects of long-term administration of bovine growth hormone on the lactational performance of identical-twin dairy cows. Animal Production 41:135-142

Piggot G.J., Baars J.A., Waller J.E.. Farrell CA. 1986. Initial development of the 'potential growth rate' concept for estimating pasture growth on farms across Northland. Proc. 1986 Agronomy Society of NZ pp. 65-69.

Roberts A.H.C., Thomson N.A. 1984. Seasonal distribution of pasture production in New Zealand XVIV. Central Taranaki. NZ Journal of Experimental Agriculture 12:93-101.

Santamaria A., McGowan A.A. 1982. The effect of contrasting winter grazing management on current and subsequent pasture production and quality. In: McMillan K.L.. Taufa V.K. (Eds) Proceedings of the Conference on Dairy Production from Pasture. pp. 359-360.

Sheath G.W., Hay R.J.M., Giles K.H. 1987. Managing pastures for grazing animals. In: Nicol A.M. (Ed) Feeding Livestockon Pasture. New Zealand Society of Animal Production. Occasional Publication No. 10. pp. 65-74

Thomson N.A., 1986. Pasture consenation an aid for balancing pasture with cow requirements and maintaining pasture quality and milkfat production. In: 1966 West Coast Dainy Industry Conference pp. 76-92 